\title{
Intracranial Delivery of CLN2 Reduces Brain Pathology in a Mouse Model of Classical Late Infantile Neuronal Ceroid Lipofuscinosis
}

\author{
Marco A. Passini, ${ }^{1}$ James C. Dodge, ${ }^{1}$ Jie Bu, ${ }^{1}$ Wendy Yang, ${ }^{1}$ Qi Zhao, ${ }^{1}$ Dolan Sondhi, ${ }^{2}$ Neil R. Hackett, ${ }^{2}$ \\ Stephen M. Kaminsky, ${ }^{2}$ Qinwen Mao, ${ }^{3}$ Lamya S. Shihabuddin, ${ }^{1}$ Seng H. Cheng, ${ }^{1}$ David E. Sleat, ${ }^{4}$ Gregory R. Stewart, ${ }^{1}$ \\ Beverly L. Davidson, ${ }^{3}$ Peter Lobel, ${ }^{4}$ and Ronald G. Crystal ${ }^{2}$ \\ ${ }^{1}$ Neuroscience, Genzyme Corporation, Framingham, Massachusetts 01701, ${ }^{2}$ Genetic Medicine, Weill Medical College of Cornell University, New York, New \\ York 10021, ${ }^{3}$ Internal Medicine, University of Iowa College of Medicine, Iowa City, Iowa 52242, and ${ }^{4}$ Center for Advanced Biotechnology and Medicine, \\ Robert Wood Johnson Medical College, Piscataway, New Jersey 08854
}

Classical late infantile neuronal ceroid lipofuscinosis (cLINCL) is a lysosomal storage disorder caused by mutations in CLN2, which encodes lysosomal tripeptidyl peptidase I (TPP1). Lack of TPP1 results in accumulation of autofluorescent storage material and curvilinear bodies in cells throughout the CNS, leading to progressive neurodegeneration and death typically in childhood. In this study, we injected adeno-associated virus (AAV) vectors containing the human CLN2 cDNA into the brains of $C L N 2^{-/-}$mice to determine therapeutic efficacy. $\mathrm{AAV} 2_{\mathrm{CU}} \mathrm{hCLN} 2$ or $\mathrm{AAV} 5_{\mathrm{CU}} \mathrm{hCLN} 2$ were stereotaxically injected into the motor cortex, thalamus, and cerebellum of both hemispheres at 6 weeks of age, and mice were then killed at 13 weeks after injection. Mice treated with AAV $2_{\mathrm{CU}} \mathrm{hCLN} 2$ and AAV $5_{\mathrm{CU}} \mathrm{hCLN} 2$ contained TPP1 activity at each injection tract that was equivalent to 0.5 - and 2 -fold that of $C L N 2^{+/+}$control mice, respectively. Lysosome-associated membrane protein 1 immunostaining and confocal microscopy showed intracellular targeting of TPP1 to the lysosomal compartment. Compared with control animals, there was a marked reduction of autofluorescent storage in the AAV2 ${ }_{\mathrm{CU}} \mathrm{hCLN} 2$ and $A A V 5_{\text {CU }}$ hCLN2 injected brain regions, as well as adjacent regions, including the striatum and hippocampus. Analysis by electron microscopy confirmed a significant decrease in pathological curvilinear bodies in cells. This study demonstrates that AAV-mediated TPP1 enzyme replacement corrects the hallmark cellular pathologies of cLINCL in the mouse model and raises the possibility of using AAV gene therapy to treat CLINCL patients.

Key words: AAV; LINCL; neurodegeneration; TPP1; Batten; lysosomal storage disease

\section{Introduction}

The neuronal ceroid lipofuscinoses (NCLs) are a group of at least seven inherited lysosomal storage disorders (LSDs) characterized by the intracellular accumulation of autofluorescent storage material, which is the hallmark cellular phenotype for this disease family (Hofmann and Peltonen, 2001). In addition, many of the NCLs contain ultrastructural pathology that can be visualized by electron microscopy. These include granular osmiophilic deposits, curvilinear bodies, and fingerprint profiles for infantile NCL (INCL), classical late infantile NCL (cLINCL), and juvenile NCL, respectively (Elleder et al., 1999; Haltia, 2003; Beaudoin et al., 2004). Lysosomal pathology predominately occurs in the CNS, but some storage defect can also be found in visceral tissue (Car-

Received June 29, 2005; revised Dec. 2, 2005; accepted Dec. 5, 2005.

This work was supported by National Institutes of Health Grants U01 NS047458 (R.G.C.) and R01 NS037918 (P.L.), Batten Disease Support and Research Association, Roy J. Carver Trust, and Nathan's Battle Foundation. We thank T. Taksir, D. Griffiths, D. Matthews, P. Piepenhagen, H. Collins, M. El-Banna, E. Giannaris, E. Vassallo, L. Curtin, and Department of Comparative Medicine for assistance.

Correspondence should be addressed to Marco A. Passini, Genzyme Corporation, One Mountain Road, Framingham, MA 01701-9322. E-mail: marco.passini@genzyme.com.

DOI:10.1523/JNEUROSCI.2676-05.2006

Copyright $\odot 2006$ Society for Neuroscience $\quad$ 0270-6474/06/261334-09\$15.00/0 penter et al., 1972; Hofmann and Peltonen, 2001). cLINCL, also known as Jansky-Bielschowsky disease, is caused by mutations in CLN2 (Sleat et al., 1997) that encodes the lysosomal enzyme tripeptidyl peptidase I (TPP1) (Rawlings and Barrett, 1999; Vines and Warburton, 1999). cLINCL patients typically exhibit neurological impairment beginning at 2-4 years of age that can be verified by electroencephalography and magnetic resonance imaging (Autti et al., 1997; Williams et al., 1999). Disease progression is unyielding and leads to ataxia, mental retardation, blindness, dementia, seizures, and death between the ages of 7 and 15 years (Hofmann and Peltonen, 2001). There is currently no effective treatment for CLINCL.

Patients with cLINCL may benefit from gene therapy because it is a monogenic disease. Introducing a functional version of CLN2 to the brain by intracranial injection of a viral vector may remove storage material and rescue cells from dysfunction. This strategy was shown to be effective in other mouse and cat models of LSDs treated with adeno-associated virus (AAV) vectors (Skorupa et al., 1999; Bosch et al., 2000; Sferra et al., 2000; Frisella et al., 2001; Matalon et al., 2003; Passini et al., 2003, 2005; Cressant et al., 2004; Desmaris et al., 2004; Griffey et al., 2004; Klugmann et al., 2005; Rafi et al., 2005; Vite et al., 2005). However, 
until only recently, an appropriate mouse model was not available to test this therapeutic approach for cLINCL. Previous studies in normal rodents and nonhuman primates showed that human TPP1 protein could be expressed in the brain after intracranial injection of recombinant AAV vectors that contained the human CLN2 cDNA (Haskell et al., 2003; Sondhi et al., 2005). Those studies also demonstrate that human TPP1 protein is secreted by transduced cells and taken up by neighboring cells via receptor-mediated endocytosis, similar to that observed for other lysosomal enzymes (Neufeld, 1991).

A CLN2 knock-out mouse model of cLINCL was recently generated and characterized (Sleat et al., 2004). CLN2 $2^{-/-}$mice contain undetectable levels of TPP1 activity, which results in lysosomal pathology and progressive neurodegeneration that recapitulate the human disease (Sleat et al., 2004). In this study, we investigated the ability of AAV gene therapy to correct lysosomal storage pathology in CLN2 $2^{-/-}$mice. Our results demonstrate that the mutant brain responds to AAV-mediated TPP1 enzyme replacement by showing a substantial reduction in brain pathology. The information in this study provides proof-of-principle that delivery of human CLN2 cDNA to the diseased brain is a promising strategy for treating cLINCL.

\section{Materials and Methods}

$A A V$ vector production. The genomic structures of AAV2 $2_{C U}$ hCLN2 and AAV $5_{\text {CU }}$ hCLN2 were identical to each other and contained serotype-2 inverted terminal repeats and the human CLN2 cDNA under the control of the cytomegalovirus enhancer chicken $\beta$-actin promoter. The AAV2 ${ }_{C U}$ NULL control vector was also similar except that the human CLN2 cDNA was substituted with a noncoding DNA sequence of equal size. The detailed description of the recombinant genomes used in this study and the production and characterization of AAV2 $2_{\mathrm{CU}}$ hCLN2 and AAV $2_{\text {CU }}$ NULL were reported previously by Sondhi et al. (2005). AAV5 $5_{\mathrm{CU}}$ hCLN2 was produced by cotransfection of helper plasmid pPAK-MA5 and CLN2 plasmid pAAV2-CAG-hCLN2 in a 10-Stack CellFactory (VWR Scientific, West Chester, PA) containing human 293 cells. Seventy-two hours after transfection, cells were harvested, and viral lysate was collected, treated with benzonase, clarified by centrifugation, and purified by discontinuous iodixanol gradients. Pooled fractions containing AAV 5 were treated with $0.5 \%$ octyl glucopyranoside, loaded onto a Q-HP anion exchange column, eluted using a linear $0-1 \mathrm{M} \mathrm{NaCl}$ gradient, and concentrated by dialysis against $120 \mathrm{~g} / \mathrm{L}$ dextran-40. In vitro enzyme assays verified that AAV2 ${ }_{\text {CU }}$ hCLN2 and AAV5 ${ }_{\text {CU }}$ hCLN2 expressed TPP1. Viral vectors were made under good manufacturing practice, and the titers of $\mathrm{AAV} 2_{\mathrm{CU}} \mathrm{hCLN} 2, \mathrm{AAV} 2_{\mathrm{CU}} \mathrm{NULL}$, and AAV $5_{\text {CU }}$ hCLN2 were $2.0 \times 10^{11}$ genome copies $(\mathrm{gc}) / \mathrm{ml}$.

Injection of $A A V$ vectors into the $\mathrm{CLN} 2^{-1-}$ brain. All procedures were performed under a protocol approved by the Institutional Animal Care and Use Committee. Mice were housed under $12 \mathrm{~h}$ light/dark cycle and were provided with food and water ad libitum. The genotypes of $C L N 2^{-/-}, C L N 2^{+/-}$, and $C L N 2^{+/+}$littermates were confirmed by PCR as described previously (Sleat et al., 2004). In the pilot study, 25 CLN2 $2^{-1-}$ mice at 6 or 10 weeks of age underwent stereotaxic brain surgery and were injected into two sites along a single needle tract with AAV2 ${ }_{\text {CU }}$ hCLN2 $(n=14), \mathrm{AAV}_{\mathrm{CU}} \mathrm{NULL}(n=7)$, or saline $(n=4)$. Injections were performed in the thalamus ( $2.00 \mathrm{~mm}$ caudal to bregma, $1.75 \mathrm{~mm}$ right of midline, $3.50 \mathrm{~mm}$ ventral to pial surface) and hippocampus $(2.00 \mathrm{~mm}$ caudal to bregma, $1.75 \mathrm{~mm}$ right of midline, $1.75 \mathrm{~mm}$ ventral to pial surface) of the right hemisphere. Three microliters $\left(6.0 \times 10^{8} \mathrm{gc}\right)$ of either vector were dispensed with a Hamilton syringe (Hamilton, Reno, $\mathrm{NV})$ into each structure for a total of $6 \mu \mathrm{l}\left(1.2 \times 10^{9} \mathrm{gc}\right)$ per brain. In the serotype comparison study, $17 C L N 2^{-/-}$mice at 6 weeks of age underwent stereotaxic brain surgery and received six injections (three per hemisphere) in six different needle tracts with AAV2 ${ }_{\text {CU }}$ hCLN2 $(n=8)$ or AAV $_{\text {CU }}$ hCLN2 $(n=9)$. Injections were done bilaterally in the motor cortex (1.00 mm rostral to bregma, $1.25 \mathrm{~mm}$ from midline, $1.25 \mathrm{~mm}$ ventral to pial surface), thalamus (2.00 mm caudal to bregma, $1.75 \mathrm{~mm}$ from midline, $3.50 \mathrm{~mm}$ ventral to pial surface), and cerebellum ( $6.00 \mathrm{~mm}$ caudal to bregma, $1.50 \mathrm{~mm}$ from midline, $1.50 \mathrm{~mm}$ ventral to pial surface). Three microliters $\left(6.0 \times 10^{8} \mathrm{gc}\right)$ of either vector were injected with a Hamilton syringe for a total of $9 \mu \mathrm{l}\left(1.8 \times 10^{9} \mathrm{gc}\right)$ per hemisphere and $18 \mu \mathrm{l}\left(3.6 \times 10^{9} \mathrm{gc}\right)$ per brain. The injections in both the pilot and serotype comparison studies were performed at a rate of $0.5 \mu \mathrm{l} / \mathrm{min}$, and the needle was left in place for $2 \mathrm{~min}$ after each injection to minimize upward flow of viral solution after raising the needle.

Evaluation of TPP1 enzyme activity in vivo. For measurement of TPP1 activity, mice were perfused with PBS, and brains were removed and cut into $2 \mathrm{~mm}$ coronal slabs using a brain matrix (Harvard Apparatus, Holliston, MA). Tissue extracts were prepared by homogenization in $150 \mathrm{~mm}$ $\mathrm{NaCl}$ and $1 \mathrm{~g} / \mathrm{L}$ Triton X-100 using a disposable pellet pestle and $1.5 \mathrm{ml}$ matching tube (Kimble-Kontes, Vineland, NJ) and clarified by centrifugation. Supernatants were analyzed for TPP1 activity as described previously (Sohar et al., 2000) after incubation at pH 3.5 to activate TPP1 precursor (Lin et al., 2001). The final activity of TPP1 was calculated by measuring the change in fluorescence units (FU) per minute per milligram of protein (standardized by BCA protein assay; Pierce, Rockford, IL).

Immunohistochemistry. Brains designated for histological analysis were drop fixed in $4 \%$ paraformaldehyde, $\mathrm{pH} 7.4$, for $48 \mathrm{~h}$, cut with a vibratome into $50 \mu \mathrm{m}$ sections, and stored free floating in KPB $(0.1 \mathrm{M}$ potassium phosphate, $\mathrm{pH} 7.4$ ) at $4^{\circ} \mathrm{C}$. Brain sections were blocked in $5 \%$ normal donkey serum, $0.2 \%$ Triton $\mathrm{X}-100$, and $0.1 \mathrm{M}$ potassium phosphate saline, $\mathrm{pH} 7.2$, for $1 \mathrm{~h}$ at room temperature (RT). A human-specific CLN2 polyclonal antibody (Haskell et al., 2003) was diluted 1:1000 in blocking solution and added to brain sections for $1 \mathrm{~h}$ at RT, followed by overnight incubation at $4^{\circ} \mathrm{C}$. An anti-rabbit biotinylated secondary antibody (Jackson ImmunoResearch, West Grove, PA) was diluted 1:250 in PBS and incubated on brain sections for $1 \mathrm{~h}$ at RT. TPP1 immunopositive cells were visualized with a streptavidin-fluorescein conjugate (Jackson ImmunoResearch). Purkinje cells were labeled with calbindin D monoclonal antibody (Sigma, St. Louis, MO) at 1:2500 dilution, neurons were labeled with neuron-specific nuclear protein $(\mathrm{NeuN})$ monoclonal antibody (Chemicon, Temecula, CA) at 1:100 dilution, astrocytes were labeled with glial fibrillary acidic protein (GFAP) monoclonal antibody (Sigma) at 1:1000 dilution, and lysosomes were labeled with lysosomeassociated membrane protein (LAMP1) monoclonal antibody (BD Biosciences, San Jose, CA) at 1:1000 dilution. Calbindin D- and GFAPpositive cells were detected with donkey anti-mouse secondary antibody conjugated to cyanine 3 (Jackson ImmunoResearch). NeuN- and LAMP1-positive cells were detected with biotinylated anti-mouse or anti-rat secondary antibody, respectively, and visualized with streptavidin-Alexa Fluor 546 conjugate (Invitrogen, Carlsbad, CA). All sections were mounted on glass slides, coverslipped with Vectashield (Vector Laboratories, Burlingame, CA), and viewed under epifluorescence and confocal microscopy.

Brain autofluorescence. Autofluorescent storage material was assessed by mounting $50 \mu \mathrm{m}$ free-floating vibratome sections from KPB storage onto glass slides, coverslipping with Vectashield, and viewing under 4',6'-diamidino-2-phenylindole epifluorescence (Sleat et al., 2004). Exposure-matched digital images were taken from comparable regions of treated and untreated brains, and the amount of autofluorescent storage was quantified using the MetaMorph Image Analysis System (Universal Imaging Corporation, Downingtown, PA). The percentage of autofluorescence in AAV-treated $C L N 2^{-1-}$ brains relative to untreated $C L N 2^{-1-}$ brains was calculated as follows: (1) storage of a given brain structure was determined in untreated $C L N 2^{-/-}$mice, and an overall average (mean) for each structure was calculated; (2) storage of the corresponding brain structures for each AAV-treated animal was determined and compared with the average autofluorescence in untreated $C L N 2^{-/-}$mice to generate a relative percentage; and (3) the relative percentages of all mice for each structure were tabulated to give an overall mean and SE.

Electron microscopy. Fifty micrometer sagittal brain sections from AAV-treated and untreated groups were dehydrated and infiltrated in $100 \%$ Spurr's resin for $24 \mathrm{~h}$, embedded between two plastic sheets, and baked at $60^{\circ} \mathrm{C}$ for $16 \mathrm{~h}$. The thalamus was dissected from the embedded 
sample, and ultrathin $50 \mathrm{~nm}$ sections were cut with a diamond knife, placed on grids, and then stained with uranyl acetate and lead citrate. Stained sections were examined with a Hitachi (Tokyo, Japan) H700 transmission electron microscope, and photos of cells with similar crosssectional area were taken. The size of inclusions was determined using the Bioquant Software (Bioquant Image Analysis Corporation, Nashville, $\mathrm{TN})$, and the total combined area of the inclusions in each cell were grouped as small ( $1 \mu \mathrm{m}^{2}$ or less), medium $\left(2-8 \mu \mathrm{m}^{2}\right)$, and large $\left(9 \mu \mathrm{m}^{2}\right.$ or greater). Three brains were processed from each group, and 40 random cells were examined in each brain for a total of 120 cells per group. The number of cells containing inclusions of different sizes were counted and compiled for statistical analysis.

Statistics. The amount of autofluorescent storage material and the number of curvilinear bodies in cells were analyzed with one-way ANOVA and Dunnett's post hoc test using GraphPad Prism version 4.0 (GraphPad Software, San Diego, CA). All values with $p<0.05$ were considered significant.

\section{Results}

Human TPP1 expression and reduction of storage pathology Storage pathology in CLN2 $2^{-/-}$mice is present by 5 weeks of age, and the progressive nature of the disease results in ataxia, seizures, and a median lifespan of 19-20 weeks (Sleat et al., 2004). An initial pilot study was conducted to determine whether $\mathrm{AAV} 2_{\mathrm{CU}}$ hCLN2 could transduce the $C L N 2^{-/-}$brain and reduce autofluorescent storage. $C L N 2^{-/-}$mice were either 10 weeks (cohort 1) or 6 weeks (cohort 2) of age at time of surgery. A total of $1.2 \times 10^{9} \mathrm{gc}$ of AAV2 $2_{\mathrm{CU}}$ hCLN2 or AAV2 $2_{\mathrm{CU}} \mathrm{NULL}$ were injected along a single needle tract into the thalamus and hippocampus of the right hemisphere. Mice from cohort 1 were killed at 6 weeks after injection and processed for TPP1 activity and expression. Mice from cohort 2 were killed at 13 weeks after injection and analyzed for TPP1 expression and reduction of autofluorescent storage material.

For biochemical analysis at 6 weeks after injection, brains treated with $\mathrm{AAV} 2_{\mathrm{CU}}$ hCLN2 $(n=6), \operatorname{AAV} 2_{\mathrm{CU}} \mathrm{NULL}(n=3)$, or saline $(n=2)$ were separated into two hemispheres. Each hemisphere was further dissected into $2 \mathrm{~mm}$ coronal slabs, homogenized, and analyzed for TPP1 activity (Fig. 1). The background TPP1 activity as defined by multiple assays of untreated $C L N 2^{-/-}$ mouse brain homogenate was $150 \pm 120 \mathrm{FU} \cdot \mathrm{min}^{-1} \cdot \mathrm{mg}^{-1}$ protein, in contrast to the average activity of $32,800 \pm 6800$ $\mathrm{FU} \cdot \mathrm{min}^{-1} \cdot \mathrm{mg}^{-1}$ in wild-type mouse brain. The region corresponding to the injection tract (slab 3) in AAV2 ${ }_{\mathrm{CU}}$ hCLN2-treated brains exhibited enzyme activity that approached $C L N 2^{+/+}$controls, and the two adjacent regions (slabs 2 and 4) had TPP1 activity less than that found in $C L N 2^{+/-}$control mice. In contrast, the rostralmost and caudalmost regions of the ipsilateral hemisphere (slabs 1 and 5) and the entire contralateral hemisphere had negligible TPP1 activity, comparable with $\mathrm{AAV} 2_{\mathrm{CU}} \mathrm{NULL}-$ and saline-injected $C L N 2^{-/-}$mice.

For histological analysis at 6 weeks after injection, brains treated with $\mathrm{AAV} 2_{\mathrm{CU}} \mathrm{hCLN} 2(n=4), \mathrm{AAV}_{\mathrm{CU}} \mathrm{NULL}(n=2)$, and saline $(n=1)$ were cut into $50 \mu \mathrm{m}$ vibratome sections and analyzed by immunohistochemistry to determine the TPP1 expression pattern in situ. AAV2 ${ }_{\text {CU }}$ hCLN2-treated brains had many TPP1 immunopositive cells concentrated around the injection sites in the ipsilateral hippocampus and thalamus (Fig. 2). Confocal microscopy showed TPP1 in a punctate cytoplasmic staining pattern that colocalized with LAMP1, indicating that TPP1 was targeted to the lysosomes (Fig. $2 D-F$ ). Although the majority of expression was localized to the cytoplasm, a portion of TPP1 was also observed in dendrites (Fig. 2G). Ecoptic distribution of TPP1 to dendritic structures may be attributable to over-

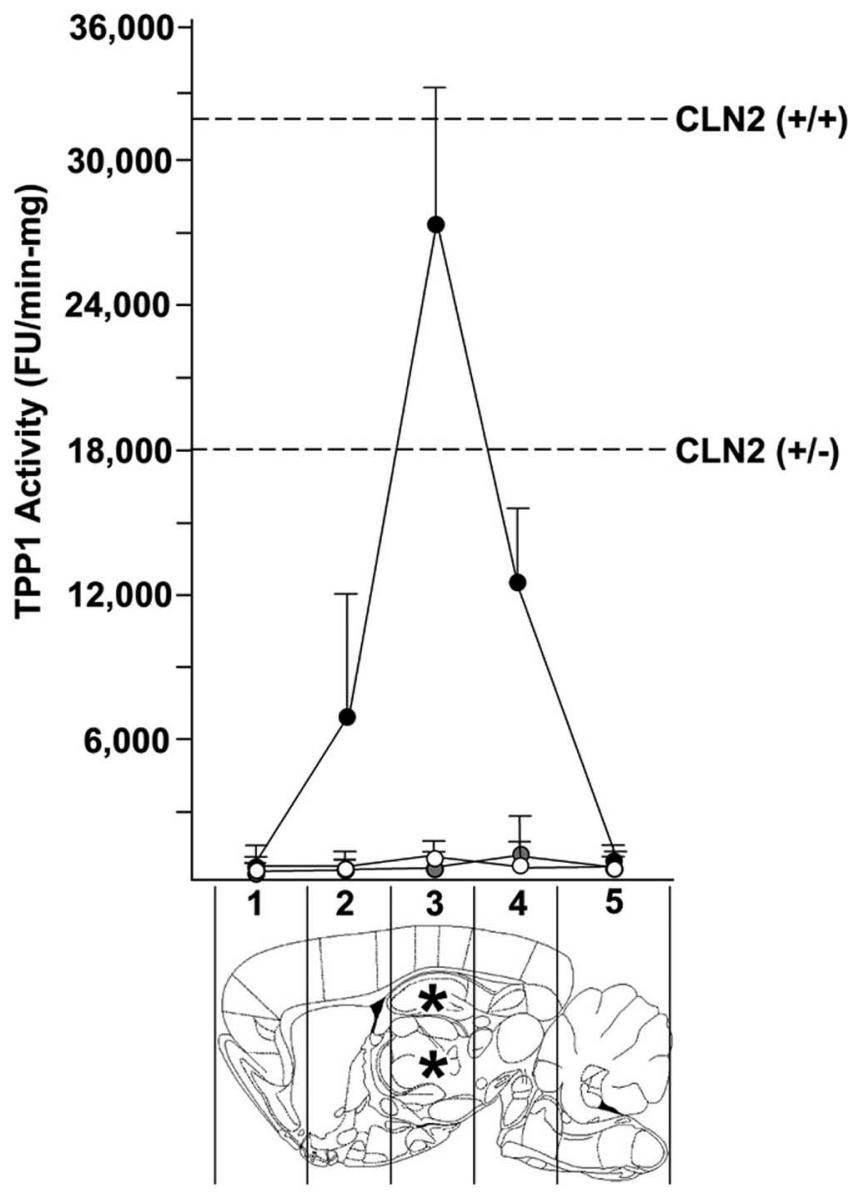

Figure 1. TPP1 activity in the $C L N 2^{-/-}$brain at 6 weeks after injection. Brains were cut into $2 \mathrm{~mm}$ coronal slabs as shown at the bottom, with corresponding amount of enzyme activity plotted above for the following samples: $A A V 2_{C U}$ hCLN2 ipsilateral hemisphere (black circles), $A A V 2_{C U}$ hCLN2 contralateral hemisphere (gray circles), and control AAV2 ${ }_{C U} N U L L$ or saline ipsilateral hemisphere (white circles). TPP1 activity approached wild-type levels in the brain slab (3) that contained the hippocampus and thalamus injection sites. The two adjacent slabs ( 2 and 4) contained some elevated levels of TPP1 activity. The rostral brain (slab 1), cerebellum (slab 5), and the entire contralateral (uninjected) hemisphere of $A A V 2_{C U}$ hCLN2-treated brains had levels of enzyme activity indistinguishable from $A A V 2_{C U}$ NULL-treated and saline brains. The dashed lines correspond to the relative levels of TPP1 activity in untreated $C L N 2^{+/-}$and $C L N 2^{+/+}$ control brains. The total number of animals was $n=6$ for AAV2 ${ }_{C U}$ hCLN2 injected and $n=5$ for control injected ( $A A V 2_{C U} N U L L$ and saline). Asterisks in the brain image show location of the injection sites. Data are means \pm SEM.

abundance of expressed protein in transduced cells. Similarly, viral vector-mediated expression of other lysosomal enzymes resulted in labeling of dendrites and, in some cases, labeling of axonal tracts (Passini et al., 2002; Haskell et al., 2003; Hennig et al., 2003; Griffey et al., 2005; Luca et al., 2005). Consistent with the enzyme activity data (Fig. 1), there was negligible TPP1 expression in regions distal to the injection site, including the motor cortex, cerebellum, the contralateral hemisphere, and in

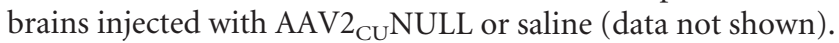

The efficacy of AAV2 gene therapy for treating autofluorescent storage was determined. Mice from cohort 2 were allowed to survive to 19 weeks (13 weeks after injection) so that a direct comparison could be made with end-stage $C L N 2^{-1-}$ control mice that normally accumulate a substantial (maximum) amount of storage at this age and die (Sleat et al., 2004). Immunohistochemistry verified the presence of TPP1 in the brain (Fig. $3 A, B)$, with an expression pattern similar to mice at 6 weeks after injection. There was a substantial decrease in autofluorescent 


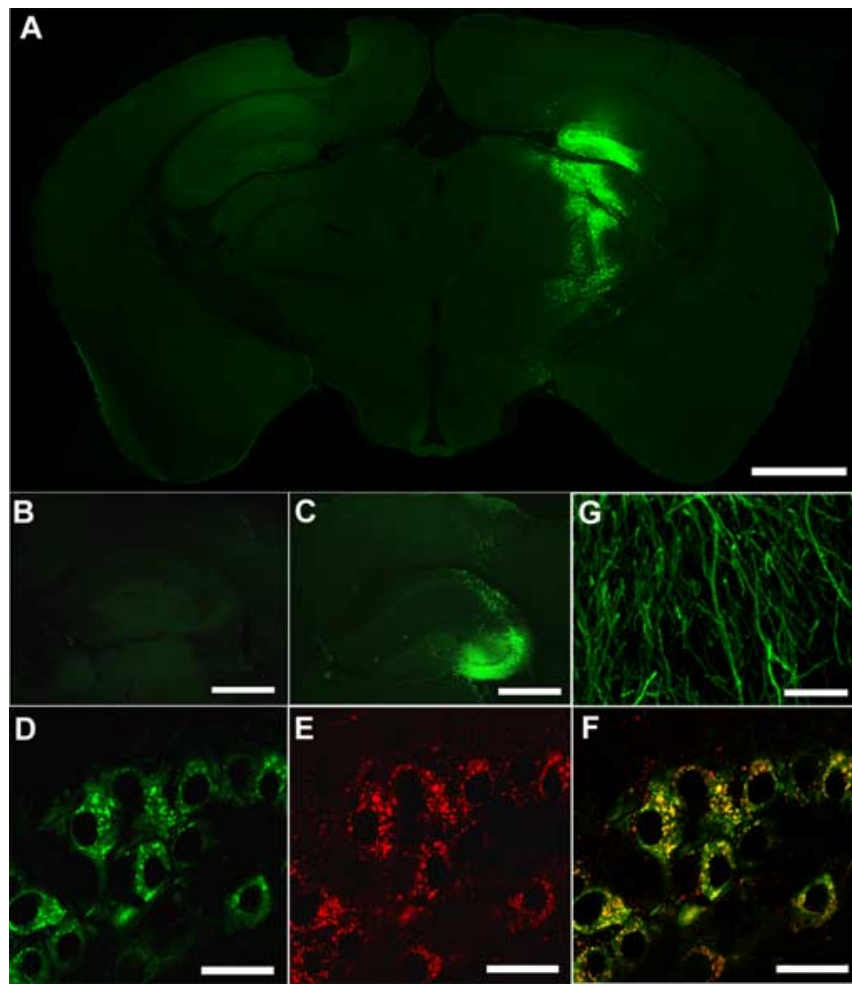

Figure 2. TPP1 expression in the $C L N 2^{-/-}$brain at 6 weeks after injection with AAV2 ${ }_{C U}$ hCLN2. TPP1 immunopositive cells were detected in the hippocampus and thalamus of the ipsilateral hemisphere but not in the contralateral hemisphere $(\boldsymbol{A})$. Close-up of the ipsilateral hippocampus showed that there was no detectable TPP1 immunostaining in untreated brains $(\boldsymbol{B})$ compared with robust TPP1 immunostaining in AAV2 ${ }_{C U}$ hCLN2-treated brains (C). High-magnification confocal images of cell bodies in the hippocampus demonstrated that TPP1 $(\boldsymbol{D})$ and LAMP1 $(\boldsymbol{E})$ were present in an overlapping punctate pattern $(\boldsymbol{F}$, yellow signal). Highmagnification confocal images of CA3 pyramidal dendrites showed positive immunostaining for TPP1 (G). Scale bars: $\boldsymbol{A}, 1 \mathrm{~mm} ; \boldsymbol{B}, \boldsymbol{C}, 100 \mu \mathrm{m} ; \boldsymbol{D}-\mathbf{G}, 20 \mu \mathrm{m}$.

storage material in the ipsilateral hippocampus and thalamus with $\mathrm{AAV} 2_{\mathrm{CU}}$ hCLN2 (Fig. $3 C, D$ ) but not with $\mathrm{AAV} 2_{\mathrm{CU}} \mathrm{NULL}$ (Fig. $3 E, F)$. The amount of storage reduction was quantified using the MetaMorph System Analysis software (see Materials and Methods). The hippocampus and thalamus of AAV2 ${ }_{\mathrm{CU}}$ hCLN2-treated CLN2 ${ }^{-/-}$brains $(n=4)$ contained an average of $39.3 \pm 11.8$ and $30.8 \pm 7.1 \%$ autofluorescence storage material relative to AAV2 ${ }_{\mathrm{CU}} \mathrm{NULL}$ - and saline-injected $C L N 2^{-1-}$ mice $(n=3)$, respectively $(p<0.05)$. However, distal structures in the ipsilateral hemisphere and the entire contralateral hemisphere of $\mathrm{AAV} 2_{\mathrm{CU}} \mathrm{hCLN} 2$-treated mice contained autofluorescent storage that was equivalent to that found in age-matched $\mathrm{AAV} 2{ }_{\mathrm{CU}} \mathrm{NULL}$ and saline $C L N 2^{-/-}$control mice (data not shown). Untreated $C L N 2^{+/+}$mice had virtually no detectable autofluorescence in the brain (Fig. $3 G, H$ ).

\section{Comparison of AAV2 and AAV5 vectors in CLN2 $2^{-/-}$mice}

The pilot study showed that AAV2 gene therapy could reduce autofluorescent storage in the CLN2 $2^{-/-}$mouse brain. However, other AAV serotype vectors may provide more effective therapy. AAV5 is a good candidate to deliver the human CLN2 cDNA because this serotype showed improved transduction of mammalian brain compared with AAV2 (Davidson et al., 2000; Burger et al., 2004; Cressant et al., 2004; Desmaris et al., 2004; Paterna et al., 2004). We thus compared the overall efficacy of titer-matched AAV2 ${ }_{\mathrm{CU}}$ hCLN2 $(n=8)$ and AAV $5_{\mathrm{CU}} \mathrm{hCLN} 2(n=9)$ after bilateral injection into the motor cortex, thalamus, and cerebellum of 6-week-old $C L N 2^{-/-}$mice. These structures contain high levels of cellular pathology and represent challenging regions to determine the efficacy of gene therapy vectors. A total of $6.0 \times 10^{8} \mathrm{gc}$ of either serotype was injected into each structure.

At 13 weeks after injection, mice were killed and brain hemispheres were separated from each other. The left hemisphere was analyzed for TPP1 activity, and the right hemisphere was analyzed for TPP1 expression and for the reduction of autofluorescent storage material and curvilinear bodies. AAV2 ${ }_{\text {CU }}$ hCLN2treated mice produced TPP1 activity similar to $C L N 2^{+/-}$controls in corresponding tissue slabs containing the motor cortex (slab 2), thalamus (slab 3), and cerebellum (slab 5) (Fig. 4). In contrast, AAV5 ${ }_{\mathrm{CU}} \mathrm{CLN} 2$-treated mice produced TPP1 activity approximately twofold higher than $C L N 2^{+/+}$control mice in these same three regions (Fig. 4). There were essentially null levels of TPP1 activity in slab 4 of AAV2 ${ }_{\mathrm{CU}}$ hCLN2- and $\mathrm{AAV} 5_{\mathrm{CU}}$ hCLN2-treated brains, indicating that there was no significant diffusion of virus or TPP1 protein.

Immunohistochemical analysis of the right hemisphere confirmed the presence of TPP1 in brain. A sagittal view at the level of the thalamic injection site showed many TPP1 immunopositive cells with $\mathrm{AAV} 2_{\mathrm{CU}}$ hCLN2 and $\mathrm{AAV} 5_{\mathrm{CU}}$ hCLN2 (Fig. $5 A, B$ ). TPP1 cells were also detected in the injected motor cortex and cerebellum (Fig. 5C-E). TPP1 was targeted to the lysosomes as verified by LAMP1 immunostaining (data not shown). Colocalization of TPP1 with NeuN showed that the majority of transduced cells were neurons (Fig. 5F, G). Neither serotype vector transduced astrocytes, as demonstrated by the lack of colocalization with GFAP (Fig. 5H,I). Double immunostaining with calbindin (red) and TPP1 (green) showed colocalization of signal (yellow) in Purkinje cells of the cerebellum (Fig. 5J-M). Although not all Purkinje cells contained exogenous protein, there were substantially more Purkinje cells positive for TPP1 with $\mathrm{AAV} 5_{\mathrm{CU}}$ hCLN2 compared with AAV2 ${ }_{\mathrm{CU}}$ hCLN2. This observation is consistent with the natural tropism of AAV5 for this cell layer after cerebellar injection (Alisky et al., 2000). However, there were regions in both the AAV5- and AAV2-treated cerebellum that were negative for calbindin, indicating that there was some Purkinje cell loss (Fig. 5I). Outside the injection sites, scattered TPP1 immunopositive cells were detected in nearby striatum and hippocampus with both vectors. TPP1 was also routinely detected in the ependyma with AAV $5_{\mathrm{CU}}$ hCLN2 but not with AAV2 ${ }_{\mathrm{CU}}$ hCLN2, which is consistent with the strong infectivity of AAV5 for the ventricular lining (Davidson et al., 2000; Watson et al., 2005).

Similar to our pilot study, untreated $C L N 2^{-/-}$mice contained abundant levels of autofluorescence at 19 weeks of age (Fig. 6 A$C$ ). The robust TPP1 immunostaining observed in the brain (Fig. 5 ) resulted in a substantial decrease of autofluorescent storage in the corresponding brain structures (Fig. 6D-I). As determined using the MetaMorph Image Analysis System, AAV-treated mice contained $\sim 30-70 \%(p<0.05)$ autofluorescent storage in the motor cortex, thalamus, cerebellum, striatum, and hippocampus compared with untreated CLN2 $2^{-1-}$ mice (Fig. $6 J$ ). There was no significant difference between the two vectors in the amount of autofluorescence that was cleared. However, regions distal to the injection tracts, such as the caudal neocortex and brainstem, had little-to-no reduction of autofluorescent storage, consistent with the negligible levels of TPP1 activity in these regions (slab 4) (Fig. 4).

The ultrastructural hallmark phenotype in cLINCL patients is curvilinear bodies. A random sampling of 120 cells along the anteroposterior and mediolateral axes of the thalamus (40 cells 
per brain, three brains per group) by electron microscopy showed that this pathological marker was found in many cells of CLN2 $2^{-1-}$ mice (Fig. 7A) but never in $C L N 2^{+/-}$mice (Fig. 7B). CLN2 $2^{-1-}$ mice treated with AAV2 ${ }_{\mathrm{CU}}$ hCLN2 (Fig. $7 C$ ) or AAV5 $5_{\mathrm{CU}}$ hCLN2 (Fig. 7D) had significantly $(p<0.01)$ less number of cells positive for curvilinear bodies in the thalamus compared with untreated $C L N 2^{-/-}$mice (Fig. 7E). Furthermore, the curvilinear bodies in cells that did contain them were smaller in size than those found in untreated $C L N 2^{-1-}$ mice (Fig. $7 E$ ). For example, only 0.8 and $2.5 \%$ of cells in AAV2 $2_{\mathrm{CU}}$ hCLN2- and AAV5 $5_{\mathrm{CU}}$ hCLN2treated brains contained inclusions $9 \mu \mathrm{m}^{2}$ or greater, respectively $(p<0.01)$. This was in contrast to untreated $C L N 2^{-1-}$ mice in which $26 \%$ of cells contained curvilinear bodies of this size.

\section{Discussion}

Collectively, the NCL ("Batten") family are the most prevalent neurological genetic disorders affecting children (Hofmann and Peltonen, 2001). cLINCL is a type of NCL that is caused by mutations in the CLN2 locus on chromosome 11 (Sleat et al., 1997). A mouse model was recently generated by targeted disruption of the CLN2 gene (Sleat et al., 2004). CLN2 ${ }^{-/-}$mice contain many of the neurological deficits found in CLINCL patients, such as ataxia, loss of motor function, brain atrophy, axonal degeneration, and the intracellular accumulation of autofluorescent storage and curvilinear bodies throughout the brain (Sleat et al., 2004). Storage pathology in CLN2 $2^{-/-}$mice is present by 5 weeks of age, the earliest time examined (Sleat et al., 2004). The progressive nature of the disease and the global neuropathology in CLN2 $2^{-1-}$ mice result in a median lifespan of 19-20 weeks.

The present study shows that $C L N 2^{-1-}$ mouse brains injected with $\mathrm{AAV} 2_{\mathrm{CU}}$ hCLN2 or AAV $5_{\mathrm{CU}} \mathrm{hCLN} 2$ contain substantially less autofluorescent storage and curvilinear bodies than untreated mutants. Colocalization with LAMP1 and subsequent decrease in cellular pathology indicates that human TPP1 was targeted to lysosomes. The amount of lysosomal pathology reduced in treated animals were comparable between the two serotype vectors despite the higher levels of TPP1 activity resulting from AAV $5_{\text {CU }}$ hCLN2. This suggests that enzyme activity above a certain threshold amount may not provide additional therapeutic relief. Typically, restoration of activity to $10-15 \%$ of normal levels is sufficient to correct storage pathology in the majority of LSDs, and this is often accepted as a target for gene therapy (Neufeld, 1991; Kaye and Sena-Esteves, 2002).

$\mathrm{AAV}$-mediated enzyme replacement therapy is effective in preventing new storage from accumulating and/or degrading existing storage. Brains treated with $\mathrm{AAV} 2_{\mathrm{CU}} \mathrm{hCLN} 2$ or AAV $5_{\text {CU }}$ hCLN2 had an average of $30-70 \%$ autofluorescent storage in structures targeted by the viral vectors compared with untreated $C L N 2^{-1-}$ mice. There were a few AAV-treated animals that contained $\sim 10 \%$ autofluorescent storage in the injected structures, which is an almost complete reduction of pathology. Electron microscope analysis also shows that only $16-26 \%$ of cells in AAV-treated brains had discernable curvilinear bodies compared with $59 \%$ in untreated $C L N 2^{-/-}$mice. Furthermore, the cells in AAV-treated brains that did contain these ultrastruc- tural inclusions were smaller and rarely approached the $9 \mu \mathrm{m}^{2}$ size that was frequently observed in untreated $C L N 2^{-/-}$mice. These data are encouraging because lysosomal storage in cLINCL patients and in $C L N 2^{-/-}$mice form highly insoluble aggregates that could be refractory to therapy (Hofmann and Peltonen, 2001). AAV gene therapy is thus an effective strategy to treat LSDs that contain aberrant storage material.

TPP1 was restricted to the injected sites and nearby structures, indicating that there was little viral and/or protein spread, which explains the lack of global correction in the brain. Although transduced cells that overexpress and secrete TPP1 can supply nontransduced cells with enzyme by mannose-6-phosphate receptor-mediated endocytosis (Lin and Lobel, 2001), this process likely occurred in the vicinity of the injection sites. A more widespread TPP1 distribution may be achieved with longer treatment or by administering AAV vector preparations (preps) with higher titers. An extended postinjection time point could provide transduced cells the time needed to "ramp-up" enzyme production, which was shown to be the case for AAV2 ${ }_{\text {CU }}$ hCLN2 in the normal rodent brain (Sondhi et al., 2005). Time points that exceeded 8 months resulted in higher enzyme activity and detection of TPP1 in areas of the brain with synaptic connections to the injection site (Sondhi et al., 2005). Similarly, widespread distribution of palmitoyl protein thioesterase (PPT) in a mouse model of INCL occurred at 7 months after injection (Griffey et al., 2005). These data suggest that distribution of TPP1 (and other NCL enzymes) may be achieved at longer time points but cannot be measured directly in the CLN2 $2^{-/-}$mouse model because of the shorter lifespan. Alternatively, injecting high-titer AAV preps may convert transduced cells into highly efficient enzyme factories for TPP1 secretion and transport in a shorter period of time. Injections into the normal rat striatum using an AAV5-hCLN2 vector that was half-log higher in titer than the one used in the current study resulted in widespread enzyme activity and evidence of cross-correction by 10 weeks after injection (Haskell et al., 2003). This was also shown for another lysosomal enzyme, in which axonal transport of $\beta$-glucuronidase was detected as early as 5-8 weeks after injection with high titer AAV in a mouse model of Mucopolysaccharidosis VII disease (Sly syndrome) (Passini et al., 2002; Hennig et al., 2003). 


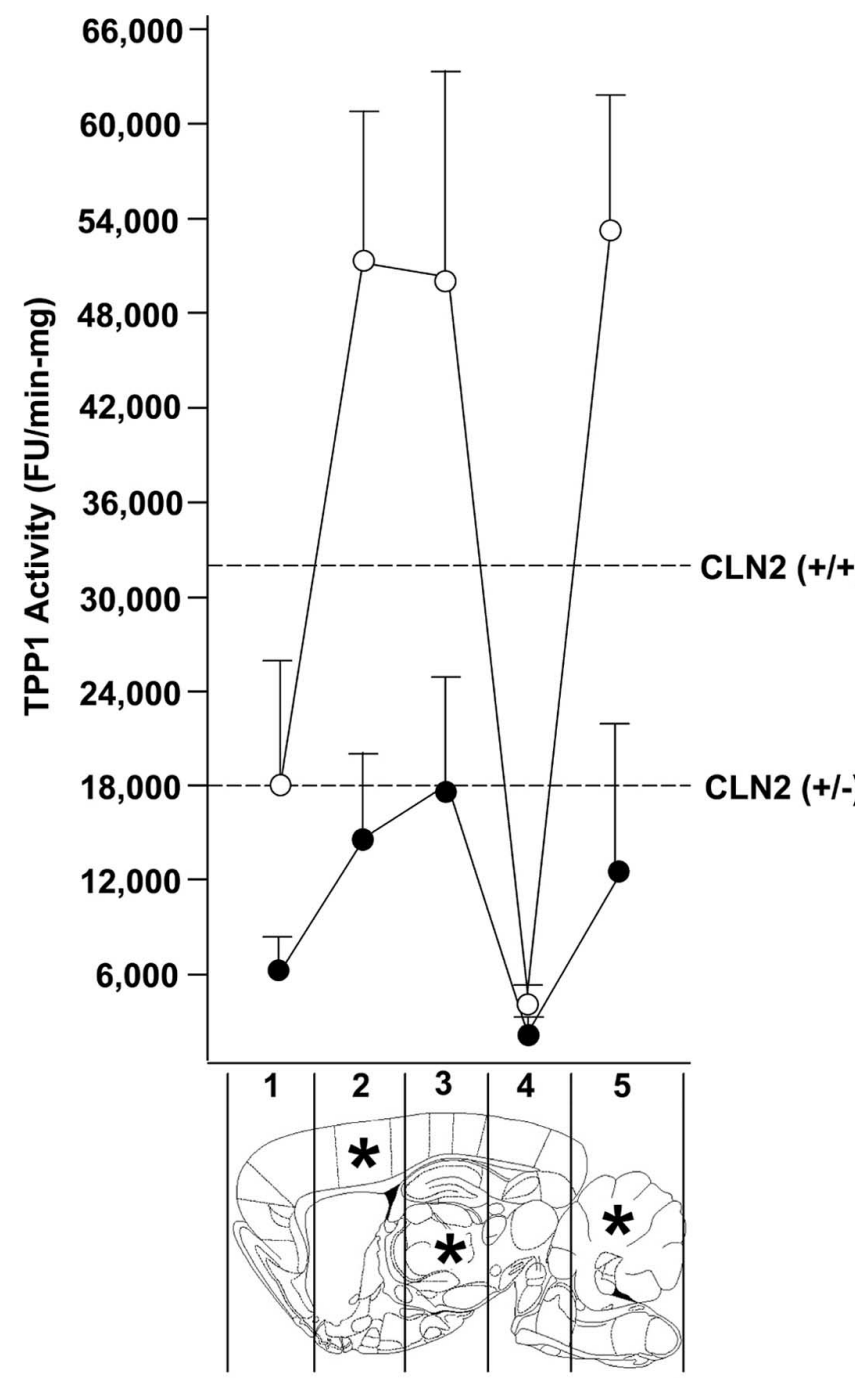

Figure 4. Comparison of TPP1 activity in $A A V_{C U}$ hCLN2- or AAV5 ${ }_{C U}$ hCLN2-treated brains at 13 weeks after injection. AAV2-injected brains (black circles) contained heterozygote levels of TPP1 activity in brain slabs containing the injection sites (slabs 2, 3,5). Despite matching titers, AAV5-injected brains (white circles) had substantially higher levels of TPP1 activity in the same corresponding brain slabs. Disparate enzyme activity was also detected in the frontal brain (slab 1) with the two serotype vectors. AAV-treated brains had essentially null levels of TPP1 activity in slab 4. The dashed lines correspond to the relative levels of TPP1 activity in untreated $\mathrm{CLN2}^{+/-}$and $\mathrm{CLN}^{+/+}$brains. Asterisks in the brain image show location of the injection sites. Data are means \pm SEM

The reasons underlying the inefficient spread of AAV are not clear. One possibility may also be attributable to the low titers of AAV used in this study because the primary attachment receptors for AAV2 and AAV5 are abundantly found in the brain (Bartlett et al., 1998; Summerford and Samulski, 1998; Walters et al., 2001). Low-titer AAV preps may become sequestered at the injection site because there would presumably be enough cellsurface receptors available to bind the majority of virions. In contrast, high-titer AAV preps may saturate cell-surface receptors at the injection site, thereby producing a gradient of virions that extend the sphere of transduction to more distal locations. High-titer AAV preps are also capable of undergoing retrograde axonal transport to distal sites, establishing secondary areas of protein production (Kaspar et al., 2002, 2003; Burger et al., 2004; Passini et al., 2005). This is also supported by a dose-response study that showed loss of axonal transport with decreasing titers
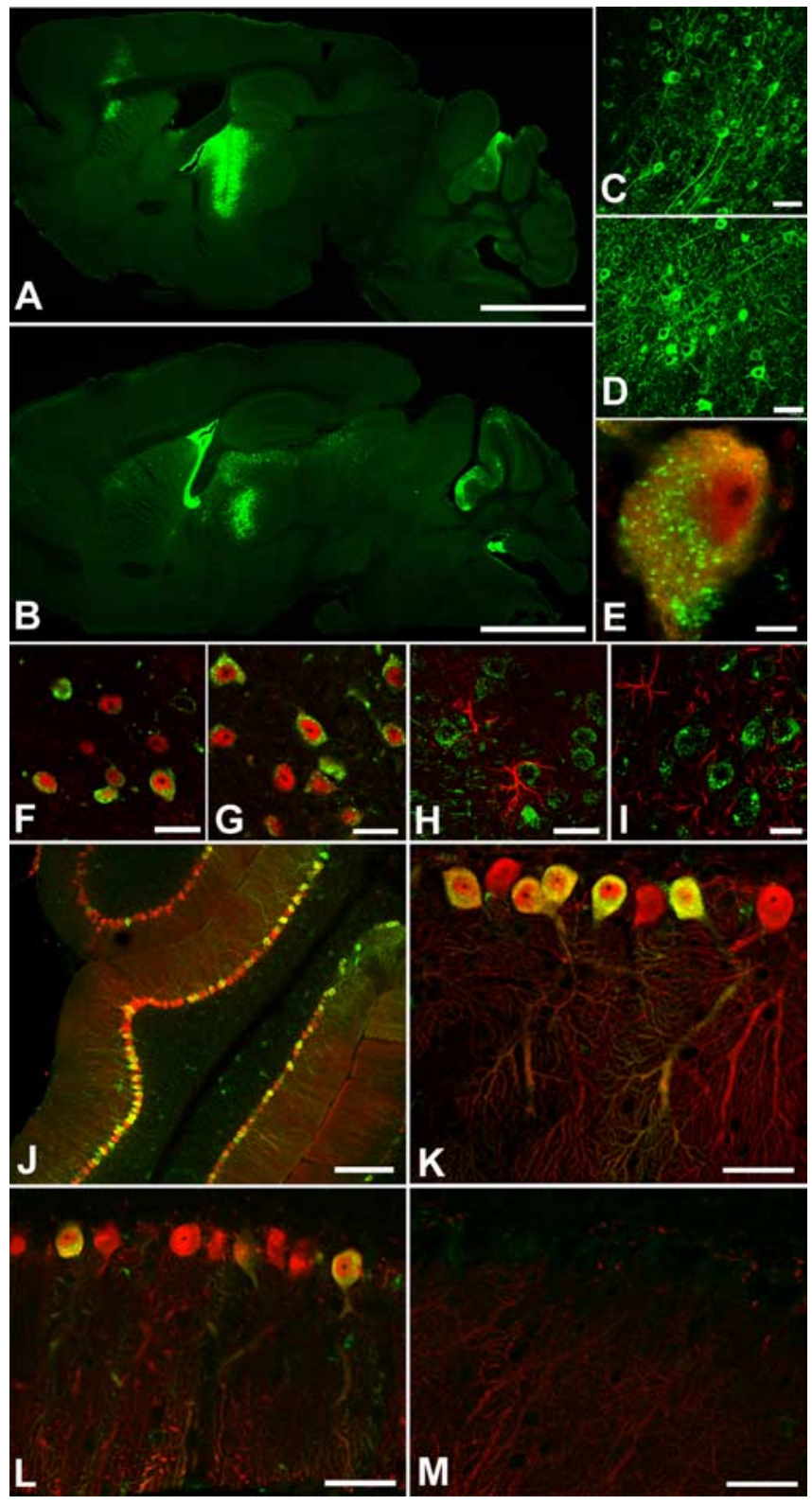

Figure 5. Comparison of TPP1 expression between $\operatorname{AAV}_{C U} \mathrm{hCLN2}(\boldsymbol{A}, \boldsymbol{C}, \boldsymbol{F}, \boldsymbol{H}, \boldsymbol{L})$ and AAV5 ${ }_{C U}$ hCLN2 $(\boldsymbol{B}, \boldsymbol{D}, \boldsymbol{E}, \boldsymbol{G}, \boldsymbol{I}-\boldsymbol{K}, \boldsymbol{M})$ at 13 weeks after injection. Robust TPP1 immunopositive cells were detected in the thalamus with AAV2 $(\boldsymbol{A})$ and AAV5 $(\boldsymbol{B})$. Adjacent sagittal sections contained many cells positive for TPP1 in the motor cortex $(\boldsymbol{C}, \boldsymbol{D})$. A 100 $\times$ confocal image of a Purkinje cell with TPP1 (green) in cytoplasmic vesicles consistent with endosomal-lysosomal targeting $(\boldsymbol{E})$. Double immunohistochemistry showed that the TPP1 (green) surrounded NeuNpositive nuclei (red), confirming that both serotype vectors were neurotrophic $(\boldsymbol{F}, \boldsymbol{G})$. In contrast, very few cells costained for TPP1 (green) and GFAP (red), demonstrating that astrocytes were inefficiently transduced by AAV2 or AAV5 $(\boldsymbol{H}, \boldsymbol{I})$. Low $(\boldsymbol{J})$ and high $(\boldsymbol{K})$ magnification confocal images of AAV5 ${ }_{C u}$ hCLN2-treated cerebellum showed that many Purkinje cells con-

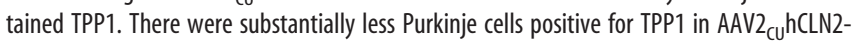
treated brains $(\boldsymbol{L})$. Purkinje cell loss in the cerebellum of an AAV5-treated brain $(\boldsymbol{M})$. Scale bars: $A, B, 2 \mathrm{~mm} ; C, D, 50 \mu \mathrm{m} ; \boldsymbol{E}, 5 \mu \mathrm{m} ; \boldsymbol{F}-I, 20 \mu \mathrm{m} ; J, 200 \mu \mathrm{m} ; \boldsymbol{K}-M, 40 \mu \mathrm{m}$.

of AAV vectors (Kaspar et al., 2003). Alternatively, widespread AAV distribution may be achieved with pressure-mediated, convection-enhanced delivery (Bankiewicz et al., 2000; Nguyen et al., 2001). Coinjection of AAV with hyperosmotic agents or molecules that bind to their receptors may also provide broader distribution (Mastakov et al., 2001; Burger et al., 2005; Hadaczek et al., 2004), although it is unclear whether toxicity associated with coinjection strategies make it useful in the clinic. 

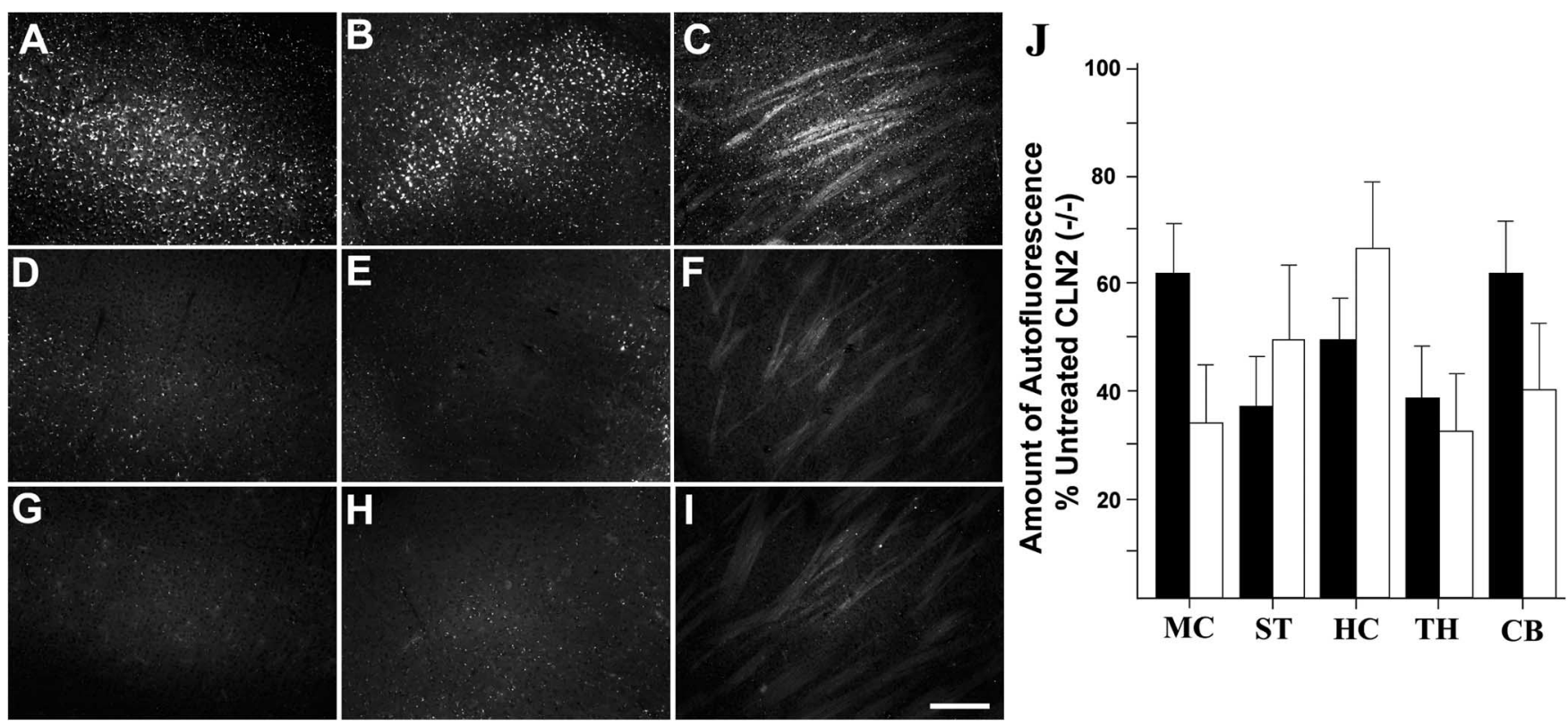

Figure 6. Reduction of brain autofluorescence with $A A V 2_{C U} h C L N 2$ or AAV5 ${ }_{C U}$ hCLN2 at 13 weeks after injection. Shown are the motor cortex $(\boldsymbol{A}, \boldsymbol{D}, \boldsymbol{G})$, thalamus $(\boldsymbol{B}, \boldsymbol{E}, \boldsymbol{H})$, and striatum $(\boldsymbol{C}, \boldsymbol{F}, \boldsymbol{I})$. Untreated $C L N 2^{-/-}$mice have high levels of autofluorescent storage material at 19 weeks of age $(\boldsymbol{A}-\boldsymbol{C})$. Injection of AAV2 ${ }_{\mathrm{Cu}} \mathrm{hCLN2}(\boldsymbol{D}-\boldsymbol{F})$ or $\mathrm{AAV}_{\mathrm{Cu}} \mathrm{hCLN}(\boldsymbol{G}-\boldsymbol{I})$ substantially reduced autofluorescent storage. The intensity of autofluorescence was quantified from exposure-matched digital images, and the results were plotted as the percentage of autofluorescent storage to untreated $\mathrm{CLN2}^{-/-}$control mice $(J)$. The background level of autofluorescence in untreated $\mathrm{CLN2}^{+/+}$mice was $<5 \%$. A total of four animals were analyzed from each group. Black bars, AAV2 ${ }_{\mathrm{Cu}} \mathrm{hCLN2}$ treated $\mathrm{CLN2}^{-1-}$ mice; white bars, AAV5 ${ }_{\mathrm{CU}} \mathrm{hCLN2} 2$-treated $\mathrm{CLN2}^{-1-}$ mice. Data are means \pm SEM. Scale bar: $250 \mu \mathrm{m}$. MC, Motor cortex; ST, striatum; HC, hippocampus; $\mathrm{TH}$, thalamus; $\mathrm{CB}$, cerebellum.

The issue of spread of expressed protein is critical in large brains and in humans. Exploiting brain circuits to distribute TPP1 by axonal transport would be beneficial for widespread distribution of enzyme in cLINCL patients. Several mouse models of LSD show potential disruption of vesicular transport through axons (Walkley, 1998). However, despite these disruptions, many lysosomal enzymes undergo axonal transport to distal locations in disease brain, such as $\beta$-glucuronidase (Passini et al., 2002; Hennig et al., 2003), arylsulfatase A (Luca et al., 2005), and acid sphingomyelinase (Dodge et al., 2005; Passini et al., 2005). PPT1 is also widely distributed in the INCL mouse, demonstrating that disease-compromised neurons of the Batten brain support axonal transport (Griffey et al., 2005). Although these data provide optimism that axonal transport may be a general property of lysosomal enzymes in affected brain, it still remains to be verified that TPP1 can become distributed through axons of the CLINCL brain.

In summary, we show that AAV-mediated TPP1 enzyme replacement is effective in reducing the hallmark cellular pathologies in a newly described CLN2 knock-out mouse model of CLINCL. The progressive nature of the disease suggests that TPP1 played a definitive role in preventing the development of storage in $C L N 2^{-/-}$brains. This would, at the minimum, provide therapeutic benefits by halting any additional progression of the dis-
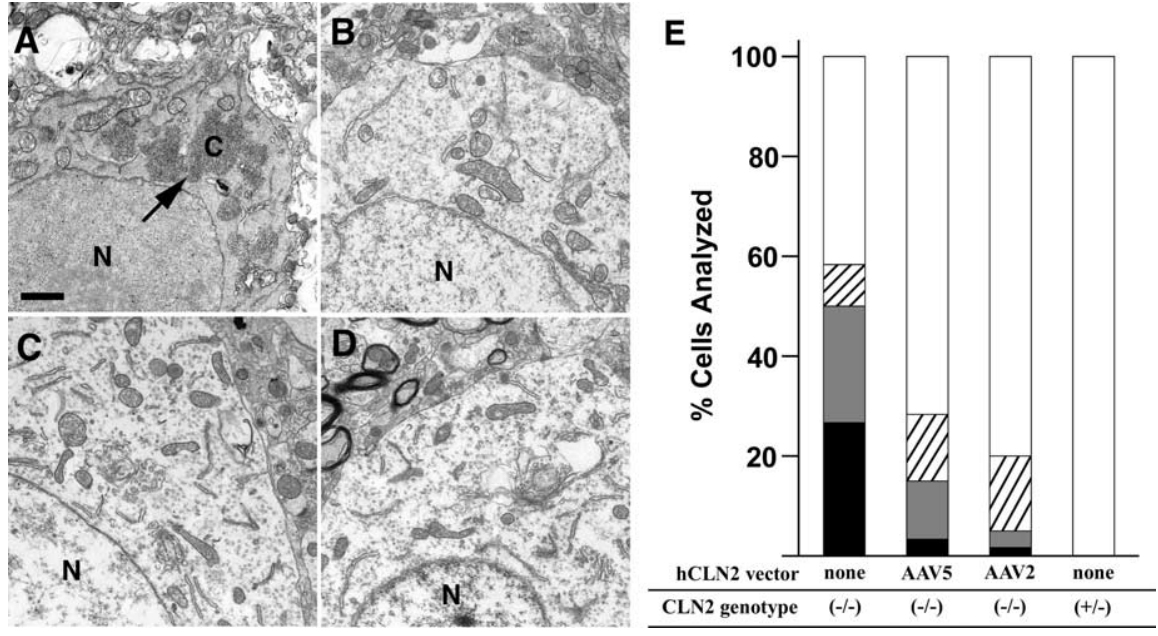

Figure 7. Electron microscope analysis of curvilinear bodies in AAV-treated and untreated thalamus. Untreated CLN2 ${ }^{-/-}$ brains contain ultrastructural inclusions (arrow) classified as curvilinear bodies $(\boldsymbol{A})$. In contrast, every cell from CLN2 ${ }^{+/-}$mice $(\boldsymbol{B})$ and the majority of cells in CLN2 $2^{-1-}$ mice treated with AAV2 $2_{C U}$ hCLN2 (C) or AAV5 ${ }_{C U}$ hCLN2 (D) did not contain these inclusions. A random sampling of 120 cells per group were analyzed, and the percentage of cells without or with curvilinear bodies of various sizes were plotted as stacked bar graphs $(\boldsymbol{E})$. Black bars, The percentage of cells that contain inclusions with a combined area of 9 $\mu \mathrm{m}^{2}$ or greater; gray bars, the percentage of cells that contain inclusions with a combined area of $2-8 \mu \mathrm{m}^{2}$; hatched bars, the percentage of cells that contain inclusions with a combined area of $1 \mu \mathrm{m}^{2}$ or less; white bars, the percentage of cells that contain no inclusions. Scale bar, $1 \mu \mathrm{m}$. C, Curvilinear body; N, nucleus. ease in CLINCL patients. TPP1 may have also degraded existing storage material because injections were done at a time when lysosomal pathology was present in the $C L N 2^{-/-}$brain. This would be particularly relevant for treating late-stage patients with severe forms of the disease. In conclusion, the information in this study provides supporting evidence that AAV gene therapy may be a potential strategy for treating cLINCL. 


\section{References}

Alisky JM, Hughes SM, Sauter SL, Jolly D, Dubensky TW, Staber PD, Chiorini JA, Davidson BL (2000) Transduction of murine cerebellar neurons with recombinant FIV and AAV5 vectors. NeuroReport 11:2669-2673.

Autti T, Raininko R, Vanhanen SL, Santavuori P (1997) Magnetic resonance techniques in neuronal ceroid lipofuscinoses and some other lysosomal diseases affecting the brain. Curr Opin Neurol 10:519-524.

Bankiewicz KS, Eberling JL, Kohutnicka M, Jagust W, Pivirotto P, Bringas J, Cunningham J, Budinger TF, Harvey-White J (2000) Convectionenhanced delivery of AAV vector in parkinsonian monkeys; in vivo detection of gene expression and restoration of dopaminergic function using pro-drug approach. Exp Neurol 164:2-14.

Bartlett JS, Samulski RJ, McCown TJ (1998) Selective and rapid uptake of adeno-associated virus type 2 in brain. Hum Gene Ther 9:1181-1186.

Beaudoin D, Hagenzieker J, Jack R (2004) Neuronal ceroid lipofuscinosis: what are the roles of electron microscopy, DNA, and enzyme analysis in diagnosis? J Histotechnol 27:237-243.

Bosch A, Perret E, Desmaris N, Heard JM (2000) Long-term and significant correction of brain lesions in adult mucopolysaccharidosis type VII mice using recombinant AAV vectors. Mol Ther 1:63-70.

Burger C, Gorbatyuk OS, Velardo MJ, Peden CS, Williams P, Zolotukhin S, Reier PJ, Mandel RJ, Muzyczka N (2004) Recombinant AAV viral vectors pseudotyped with viral capsids from serotypes 1,2 , and 5 display differential efficiency and cell tropism after delivery to different regions of the central nervous system. Mol Ther 10:302-317.

Burger C, Nguyen FN, Deng J, Mandel RJ (2005) Systemic mannitolinduced hyperosmolality amplifies rAAV2-mediated striatal transduction to a greater extent than local co-infusion. Mol Ther 11:327-331.

Carpenter S, Karpati G, Andermann F (1972) Specific involvement of muscle, nerve, and skin in late infantile and juvenile amaurotic idiocy. Neurology 22:170-186.

Cressant A, Desmaris N, Verot L, Brejot T, Froissart R, Vanier MT, Maire I, Heard JM (2004) Improved behavior and neuropathology in the mouse model of Sanfilippo type IIIB disease after adeno-associated virusmediated gene transfer in the striatum. J Neurosci 24:10229-10239.

Davidson BL, Stein CS, Heth JA, Martins I, Kotin RM, Derksen TA, Zabner J, Ghodsi A, Chiorini JA (2000) Recombinant adeno-associated virus type 2, 4, and 5 vectors: transduction of variant cell types and regions in the mammalian central nervous system. Proc Natl Acad Sci USA 97:3428-3432.

Desmaris N, Verot L, Puech JP, Caillaud C, Vanier MT, Heard JM (2004) Prevention of neuropathology in the mouse model of Hurler syndrome. Ann Neurol 56:68-76.

Dodge JC, Clarke J, Song A, Bu J, Yang W, Taksir TV, Griffiths D, Zhao Q, Schuchman EH, Cheng SH, O'Riordan CR, Shihabuddin LS, Passini MA, Stewart GR (2005) Intracerebellar injection of different AAV serotype vectors encoding human ASM corrects neuropathology and motor deficits in a mouse model of Niemann-Pick A disease. Proc Natl Acad Sci USA 102:17822-17827.

Elleder M, Lake BD, Goebel HH, Rapola J, Haltia M, Carpenter S (1999) Definitions of the ultrastructural patterns found in NCL. In: The neuronal ceroid lipofuscinoses, Ed 1 (Goebel HH, Mole SE, Lake BD, eds), pp 5-15. Amsterdam: IOS.

Frisella WA, O'Connor LH, Vogler CA, Roberts M, Walkley S, Levy B, Daly TM, Sands MS (2001) Intracranial injection of recombinant adenoassociated virus improves cognitive function in a murine model of mucopolysaccharidosis type VII. Mol Ther 3:351-358.

Griffey M, Bible E, Vogler C, Levy B, Gupta P, Cooper J, Sands MS (2004) Adeno-associated virus 2-mediated gene therapy decreases autofluorescent storage material and increases brain mass in a murine model of infantile neuronal ceroid lipofuscinosis. Neurobiol Dis 16:360-369.

Griffey M, Macauley SL, Ogilvie JM, Sands MS (2005) AAV2-mediated ocular gene therapy for infantile neuronal ceroid lipofuscinosis. Mol Ther 12:413-421.

Hadaczek P, Mirek H, Bringas J, Cunningham J, Bankiewicz K (2004) Basic fibroblast growth factor enhances transduction, distribution, and axonal transport of adeno-associated virus type 2 vector in rat brain. Hum Gene Ther 15:469-479.

Haltia M (2003) The neuronal ceroid lipofuscinoses. J Neuropathol Exp Neurol 62:1-13.

Haskell RE, Hughes SM, Chiorini JA, Alisky JM, Davidson BL (2003) Viral- mediated delivery of the late-infantile neuronal ceroid lipofuscinosis gene, TPP-I to the mouse central nervous system. Gene Ther 10:34-42.

Hennig AK, Levy B, Ogilvie JM, Vogler CA, Galvin N, Bassnett S, Sands MS (2003) Intravitreal gene therapy reduces lysosomal storage in specific areas of the CNS in mucopolysaccharidosis VII mice. J Neurosci 23:3302-3307.

Hofmann SL, Peltonen L (2001) The neuronal ceroid lipofuscinoses. In: The metabolic and molecular basis of inherited disease, Ed 8 (Scriver CR, Beaudet AL, Sly WS, Valle D, eds), pp 3877-3894. New York: McGraw-Hill.

Kaspar BK, Erickson D, Schaffer D, Hinh L, Gage FH, Peterson DA (2002) Targeted retrograde gene delivery for neuronal protection. Mol Ther 5:50-56.

Kaspar BK, Llado J, Sherkat N, Rothstein JD, Gage FH (2003) Retrograde viral delivery of IGF-1 prolongs survival in a mouse ALS model. Science 301:839-842.

Kaye EM, Sena-Esteves M (2002) Gene therapy for the central nervous system in the lysosomal storage disorders. Neurol Clin N Am 20:879-901.

Klugmann M, Leichtlein CB, Symes CW, Serikawa T, Young D, During MJ (2005) Restoration of aspartoacylase activity in CNS neurons does not ameliorate motor deficits and demyelination in a model of Canavan disease. Mol Ther 11:745-753.

Lin L, Lobel P (2001) Production and characterization of recombinant human CLN2 protein for enzyme-replacement therapy in late infantile neuronal ceroid lipofuscinosis. Biochem J 357:49-55.

Lin L, Sohar I, Lackland H, Lobel P (2001) The human CLN2 protein/ tripeptidyl-peptidase I is a serine protease that autoactivates at acidic $\mathrm{pH}$. J Biol Chem 276:2249-2255.

Luca T, Givogri MI, Perani L, Galbiati F, Follenzi A, Naldini L, Bongarzone ER (2005) Axons mediate the distribution of arylsulfatase a within the mouse hippocampus upon gene delivery. Mol Ther 12:669-679.

Mastakov MY, Baer K, Xu R, Fitzsimons H, During MJ (2001) Combined injection of rAAV with mannitol enhances gene expression in the rat brain. Mol Ther 3:225-232.

Matalon R, Surendran S, Rady PL, Quast MJ, Campbell GA, Matalon KM, Tyring SK, Wei J, Peden CS, Ezell EL, Muzyczka N, Mandel RJ (2003) Adeno-associated virus-mediated aspartoacylase gene transfer to the brain of knockout mouse for canavan disease. Mol Ther 7:580-587.

Neufeld EF (1991) Lysosomal storage diseases. Annu Rev Biochem 60:257-280.

Nguyen JB, Sanchez-Pernaute R, Cunningham J, Bankiewicz KS (2001) Convection-enhanced delivery of AAV2 combined with heparin increases TK gene transfer in the rat brain. NeuroReport 12:1961-1964.

Passini MA, Lee EB, Heuer GG, Wolfe JH (2002) Distribution of a lysosomal enzyme in the adult brain by axonal transport and by cells of the rostral migratory stream. J Neurosci 22:6437-6446.

Passini MA, Watson DJ, Vite CH, Landsburg DJ, Feigenbaum AL, Wolfe JH (2003) Intraventricular brain injection of AAV1 in neonatal mice results in complementary patterns of neuronal transduction to AAV2 and total long-term correction of storage lesions in the brains of $\beta$-glucuronidasedeficient mice. J Virol 77:7034-7040.

Passini MA, Macauley SL, Huff MR, Taksir TV, Bu J, Wu I-H, Piepenhagen PA, Dodge JC, Shihabuddin LS, O’Riordan CR, Schuchman EH, Stewart GR (2005) AAV vector-mediated correction of brain pathology in a mouse model of Niemann-Pick A disease. Mol Ther 11:754-762.

Paterna JC, Feldon J, Bueler H (2004) Transduction profiles of recombinant adeno-associated virus vectors derived from serotypes 2 and 5 in the nigrostriatal system of rats. J Virol 78:6808-6817.

Rafi MA, Rao HZ, Passini MA, Curtis M, Vanier MT, Zaka M, Luzi P, Wolfe JH, Wenger DA (2005) AAV-mediated expression of galactocerebrosidase in brain results in attenuated symptoms and extended life span in murine models of globoid cell leukodystrophy. Mol Ther 11:734-744.

Rawlings ND, Barrett AJ (1999) Tripeptidyl-peptidase I is apparently the CLN2 protein absent in classical late-infantile neuronal ceroid lipofuscinosis. Biochim Biophys Acta 1429:496-500.

Sferra TJ, Qu G, McNeely D, Rennard R, Clark KR, Lo WD, Johnson PR (2000) Recombinant adeno-associated virus-mediated correction of lysosomal storage within the central nervous system of the adult mucopolysaccharidosis type VII mouse. Hum Gene Ther 11:507-519.

Skorupa AF, Fisher KJ, Wilson JM, Parente MK, Wolfe JH (1999) Sustained production of $\beta$-glucuronidase from localized sites after AAV vector gene transfer results in widespread distribution of enzyme and reversal of ly- 
sosomal storage lesions in a large volume of brain in mucopolysaccharidosis VII mice. Exp Neurol 160:17-27.

Sleat DE, Donnelly RJ, Lackland H, Liu CG, Sohar I, Pullarkat RK, Lobel P (1997) Association of mutations in a lysosomal protein with classical late-infantile neuronal ceroid lipofuscinosis. Science 277:1802-1805.

Sleat DE, Wiseman JA, El-Banna M, Kim KH, Mao Q, Price S, Macauley SL, Sidman RL, Shen MM, Zhao Q, Passini MA, Davidson BL, Stewart GR, Lobel P (2004) A mouse model of classical late-infantile neuronal ceroid lipofuscinosis based on targeted disruption of the CLN2 gene results in a loss of tripeptidyl-peptidase I activity and progressive neurodegeneration. J Neurosci 24:9117-9126.

Sohar I, Lin L, Lobel P (2000) Enzyme-based diagnosis of classical late infantile neuronal ceroid lipofuscinosis: comparison of tripeptidyl peptidase I and pepstatin-insensitive protease assays. Clin Chem 46:1005-1008.

Sondhi D, Peterson DA, Giannaris EL, Sanders CT, Mendez BS, De B, Rostkowski A, Blanchard B, Bjugstad K, Sladek JR, Redmond DE, Leopold PL, Kaminsky SM, Hackett NR, Crystal RG (2005) AAV2-mediated CLN2 gene transfer to rodent and non-human primate brain results in longterm TPP1 expression compatible with therapy for LINCL. Gene Ther 12:1618-1632.

Summerford C, Samulski RJ (1998) Membrane-associated heparan sulfate proteoglycan is a receptor for adeno-associated virus type 2 virions. J Virol 72:1438-1445.

Vines DJ, Warburton MJ (1999) Classical late infantile neuronal ceroid lipofuscinosis fibroblasts are deficient in lysosomal tripeptidyl peptidase I. FEBS Lett 443:131-135.

Vite $\mathrm{CH}, \mathrm{McG}$ owan JC, Niogi SN, Passini MA, Drobatz KJ, Haskins ME, Wolfe JH (2005) Effective gene therapy for an inherited diffuse CNS disease in a large animal model. Ann Neurol 57:355-364.

Walkley SU (1998) Cellular pathology of lysosomal storage disorders. Brain Pathol 8:175-193.

Walters RW, Yi SM, Keshavjee S, Brown KE, Welsh MJ, Chiorini JA, Zabner J (2001) Binding of adeno-associated virus type 5 to 2,3-linked sialic acid is required for gene transfer. J Biol Chem 276:20610-20616.

Watson DJ, Passini MA, Wolfe JH (2005) Transduction of the choroid plexus and ependyma in neonatal mouse brain by VSV-G pseudotyped lentivirus and adeno-associated virus type 5 vectors. Hum Gene Ther $16: 49-56$

Williams RE, Gottlob I, Lake BD, Goebel HH, Winchester BG, Wheeler RB (1999) CLN2 classic late infantile NCL. In: The neuronal ceroid lipofuscinoses, Ed 1 (Goebel HH, Mole SE, Lake BD, eds), pp 37-54. Amsterdam: IOS. 